\title{
ANALISIS KARAKTERISTIK MUTU SABUN TRANSPARAN BEKATUL BERAS MERAH (Oryza nivara) BERBAHAN DASAR MINYAK GORENG BEKAS
}

\author{
Maria Mita Susanti ${ }^{1 *}$, Syela Puspitaningtyas ${ }^{1)}$ \\ ${ }^{\text {I} P r o g r a m ~ S t u d i ~ D 3 ~ F a r m a s i ~ P o l i t e k n i k ~ K a t o l i k ~ M a n g u n w i j a y a ~}$ \\ Jl. Gajah Mada 91 Semarang-Jawa Tengah Indonesia \\ *E-mail : mythavia84@gmail.com
}

\begin{abstract}
INTISARI
Paparan radikal bebas dari aktivitas sehari-hari dapat menyebabkan kerusakan pada kulit, sehingga untuk menghindari dapat digunakan senyawa antioksidan. Bekatul beras merah merupakan limbah penggilingan padi yang memiliki antioksidan tinggi dengan $\mathrm{IC}_{50}$ yaitu $43,2349 \mathrm{ppm}$. Upaya untuk meningkatkan nilai ekonomi bekatul yang tinggi akan senyawa antioksidan adalah dengan mengolah bekatul menjadi produk sabun transparan. Penelitian ini dilakukan untuk menganalisis karakteristik mutu sabun transparan bekatul beras merah (Oryza nivara) berbahan dasar minyak goreng bekas. Karakteristik mutu sabun transparan bekatul beras merah yang dianalisis meliputi organoleptis sabun, pH, daya busa, alkali bebas, dan kadar air. Data dianalisis secara teoritis dengan dibandingkan pada persyaratan sabun menurut SNI 06-3532-1994.

Berdasarkan hasil penelitian didapatkan hasil karakteristik sabun yang memenuhi karakteristik mutu persyaratan sabun SNI 06-3532-1994 dengan hasil pH 10,2, daya busa 2,54 cm, alkali bebas $0,034 \%$, dan kadar air 3,8544\%.
\end{abstract}

Kata Kunci : sabun transparan, bekatul beras merah, minyak goreng bekas, karakteristik mutu sabun padat

\begin{abstract}
The free radicals exposure from daily activities can cause the damage the skin, therefore to avoid this damage effect can use antioxidants compounds. Brown rice bran is rice milling waste which has high antioxidant with $I C_{50}$ is 43,2349 ppm. Efforts to increase the economic value of rice bran high in antioxidant compounds is by processing rice bran into transparent soap products. This research was conducted to analyze the quality characteristics of transparent red rice bran soap (Oryza nivara) based on used cooking oil. The quality characteristics of transparent rice soap which includes organoleptic soap, $\mathrm{pH}$, foam power, free alkali, and water content. The data were analyzed descriptively by comparing the results of research with SNI 06-3532 -1994

Based on the results of the study obtained the results of the characteristics of soap that meets the quality characteristics of SNI 06-3532-1994 soap requirements with a pH of 10,2, foam power of $2,54 \mathrm{~cm}$, free alkali of 0,034\%, and 3,85\% moisture content.
\end{abstract}

Keywords : transparent soap, brown rice bran, used cooking oil, solid soap quality characteristics

*Corresponding author:

Maria Mita Susanti

Prodi D3 Farmasi Politeknik Katolik Mangunwijaya

E-mail: $\underline{\text { mythavia84@gmail.com }}$ 


\section{PENDAHULUAN}

Radikal bebas merupakan molekul yang mengandung atom yang tidak berpasangan sehingga bersifat tidak stabil dan sangat reaktif. Senyawa radikal bebas mampu menyerang berbagai molekul dalam tubuh sehingga dapat menyebabkan gangguan produksi DNA, pembuluh darah, gangguan keseimbangan dalam tubuh, dan menyebabkan kerusakan pada sel kulit (Winarsi, 2011). Paparan radikal bebas dapat terlihat pada kulit, efek yang ditimbulkan salah satunya yaitu penuaan dini (Youngson, 2005).

Efek dari radikal bebas pada kulit dapat dikurangi dengan senyawa antioksidan yang salah satunya dapat diperoleh dari bekatul, suatu limbah lapisan terluar bulir beras yang diperoleh dari proses penggilingan padi (Siswanti dkk., 2018). Hasil penelitian Tuarita dkk. (2017); Goufo dan Trindade (2014) menunjukkan bahwa bekatul mengandung komponen bioaktif seperti $\gamma$-oryzanol, asam fitat, asam fenolik, antosianin, $\alpha$-tokoferol, $\gamma$-tokoferol, tokotrienol, dan fitosterol. Pada penelitian (Suhery dan Anggraini, 2016) tentang formulasi dan evaluasi masker gel peel-off dari ekstrak bekatul beras merah dengan berbagai variasi basis, bahwa 0,5\% ekstrak bekatul beras merah memiliki aktivitas antioksidan yang paling tinggi dengan nilai $\mathrm{IC}_{50}$ sebesar 43,2349 ppm. Pemanfaatan ekstrak bekatul yang tinggi kandungan antioksidan ini dapat dibuat menjadi sediaan sabun transparan untuk mencegah adanya radikal bebas pada kulit.

Sabun transparan merupakan sabun batangan yang memiliki struktur bening. Keunggulan sabun yaitu memiliki penampakan transparan dan memiliki permukaan yang mengkilap (Momuat dan Wuntu, 2017). Pembuatan sabun dibentuk dari proses saponifikasi antara minyak atau lemak dengan alkali. Salah satu minyak yang dapat digunakan untuk bahan baku pembuatan sabun adalah minyak goreng bekas yang telah dimurnikan (Naomi dkk, 2013). Minyak goreng bekas merupakan minyak goreng yang jika digunakan secara terus menerus dapat memicu resiko timbulnya penyakit. Hal ini diakibatkan oleh perubahan struktur asam lemak pada minyak goreng bekas (Priani dan Lukmayani, 2010). Menurut penelitian Hardian dkk. (2014) telah menggunakan minyak goreng bekas yang telah dimurnikan sebagai basis pembuatan sabun transparan menghasilkan sabun yang sesuai dengan persyaratan Standar Nasional Indonesia (SNI) tahun 1994.

Berdasarkan penelitian Purwanti dkk (2017) tentang pembuatan sabun transparan dari minyak kelapa dengan penambahan antiseptik diperoleh formula sabun transparan paling baik adalah dengan menggunakan $\mathrm{NaOH} 31 \%$ sebanyak $9 \mathrm{~mL}$. Formula tersebut memenuhi syarat mutu sabun berdasarkan SNI 06-3532-1994 tentang persyaratan mutu sabun, dengan demikian formula tersebut dapat digunakan sebagai acuan dalam pembuatan sabun transparan bekatul berbahan dasar minyak goreng bekas. Berdasarkan hal tersebut, maka perlu dilakukan analisis tentang karakteristik mutu sabun transparan bekatul beras merah berbahan dasar minyak goreng bekas.

\section{METODE PENELITIAN}

\section{Bahan dan Alat}

Bahan yang digunakan adalah bekatul beras merah, minyak goreng bekas, natrium hidroksida (teknis), aquadest, asam stearat (teknis), gliserin, sukrosa, etanol 96\%, indikator phenolphtalin (Merck). Alat yang digunakan adalah neraca analitik (Ohaus), bejana maserasi, thermometer, alatalat gelas, kertas saring, kain katun, penangas air, kompor, loyang, oven, mesh ayakan 60, pH meter (Hanna), rotary evaporator (IKA), cetakan sabun.

\section{Jalannya Penelitian}

\section{Determinasi bekatul beras merah}

Bekatul beras merah yang digunakan diperoleh dari daerah Sawangan, Kabupaten Magelang. Tanaman beras merah dideterminasi dengan tujuan untuk memastikan kebenaran identitas dari tanaman berasal dari spesies Oryza nivara S. D. Sharma \& Shastry.

\section{Stabilisasi bekatul beras merah}

Stabilisasi dilakukan dengan memasukkan sampel bekatul ke dalam oven pada suhu $80^{\circ} \mathrm{C}$ selama 1 jam. Pada proses stabilisasi digunakan oven untuk menginaktivasi enzim lipase dalam bekatul dan dapat menurunkan kadar air bekatul (Kim dkk., 2014). 


\section{Ekstraksi bekatul beras merah}

Bekatul yang telah dilakukan stabilisasi ditimbang sebanyak $500 \mathrm{~g}$ dimaserasi menggunakan etanol $96 \%$ yang telah diasamkan dengan $\mathrm{HCl} 37 \%$ sampai $\mathrm{pH} 1$ dengan perbandingan bekatul dengan pelarut 1:6 (b/v). Maserasi dilakukan selama 30 jam sambil diaduk 4 jam sekali. Maserat diuapkan menggunakan rotary evaporator dan penangas air (Suhery dan Anggraini, 2016).

\section{Uji kadar asam lemak bebas minyak goreng bekas}

Minyak goreng bekas maksimal 3 kali pemakaian sebanyak 20 g kemudian ditambahkan 2 tetes indikator phenolphtalin dan dititrasi menggunakan $\mathrm{NaOH} 0,1 \mathrm{~N}$ sampai terjadi perubahan warna dari tidak berwarna menjadi merah muda mantap. Hasil titrasi yang terbentuk dicatat dan dilakukan pengulangan sebanyak 3 kali (Utami, 2011).

\section{Pemurnian minyak goreng bekas}

\section{a. Despicing}

Minyak goreng bekas ditimbang sebanyak $500 \mathrm{~g}$, dimasukkan ke dalam beaker glass dan ditambahkan aquadest $500 \mathrm{~mL}$. Campuran minyak goreng bekas dan aquadest dipanaskan pada suhu $110^{\circ} \mathrm{C}$ sampai tersisa setengahnya, dimasukkan dalam corong pisah dan dilakukan pengendapan selama 1 jam. Fase minyak disaring menggunakan kertas saring untuk memisahkan kotoran yang tersisa (Ketaren, 2005).

b. Netralisasi

Minyak goreng hasil proses despicing dimasukkan ke dalam beaker glass sebanyak $450 \mathrm{~g}$, dipanaskan pada suhu $35^{\circ} \mathrm{C}$ kemudian ditambahkan sedikit demi sedikit larutan $\mathrm{NaOH} 10 \%$ sampai $\mathrm{pH}$ 7. Suhu ditingkatkan mencapai $40^{\circ} \mathrm{C}$ sambil diaduk 10 menit, didiamkan selama 10 menit hingga dingin dan disaring dengan kertas saring (Ketaren, 2005).

c. Bleaching

Minyak goreng hasil netralisasi ditimbang $350 \mathrm{~g}$ dipanaskan pada suhu $70^{\circ} \mathrm{C}$, dimasukkan karbon aktif $75 \mathrm{mg}$. Campuran minyak dan karbon aktif dipanaskan sampai suhu $100^{\circ} \mathrm{C}$ sambil diaduk selama 60 menit, campuran didinginkan dan disaring secara bertingkat menggunakan kertas saring (Susanti dan Priamsari, 2019).

\section{Pembuatan sabun transparan bekatul beras merah}

Sabun transparan bekatul beras merah berbahan dasar minyak goreng bekas dibuat dengan formula seperti pada Tabel I.

Tabel I. Formula Sabun Bekatul Transparan Berbahan Dasar Minyak Goreng Bekas

\begin{tabular}{lcc}
\hline \multicolumn{1}{c}{ Formula } & Konsentrasi (\%) & Fungsi \\
\hline Minyak goreng bekas & 25 & fase minyak \\
NaOH 31\% & 4,5 & fase basa \\
Asam stearat & 6 & surfactan \\
Etanol 96\% & 27,5 & pelarut \\
Gliserin & 10 & humectan \\
Sukrosa & 5 & transparent agent \\
Ekstrak bekatul & 1,5 & zat utama \\
Aquadest add & 100 & pelarut \\
\hline
\end{tabular}

Ditimbang $6 \mathrm{~g}$ asam stearat dipanaskan pada suhu $60^{\circ} \mathrm{C}$ hingga meleleh. Minyak goreng hasil pemurnian sebanyak $25 \mathrm{~mL}$ dipanaskan pada suhu $60^{\circ} \mathrm{C}$. Asam stearat yang sudah mencair ditambahkan dalam minyak sambil diaduk. $\mathrm{NaOH} 31 \%$ sebanyak $4,5 \mathrm{~mL}$ ditambahkan sedikit demi sedikit sambil diaduk cepat hingga terbentuk campuran homogen sambil dipanaskan pada suhu $70^{\circ} \mathrm{C}$. Sukrosa $5 \mathrm{~g}$ dihaluskan dan dilarutkan dalam aquadest ditambahkan dalam campuran dan diaduk selama 5 menit. Gliserin $10 \mathrm{~mL}$ ditambahkan sambil diaduk kemudian ditambahkan etanol 96\% 27,5 mL dan ekstrak bekatul beras merah $1,5 \mathrm{~mL}$ diaduk selama 5 menit. Sabun dituang pada cetakan, dibiarkan dingin pada suhu ruang. 


\section{Pengujian karakteristik sabun}

a. Uji organoleptis

Pengujian organoleptis dilakukan dengan mengamati sediaan sabun transparan yang meliputi bentuk, bau, dan warna sediaan.

b. Uji pH

Pengujian $\mathrm{pH}$ dilakukan dengan cara menimbang $1 \mathrm{~g}$ sabun transparan yang dilarutkan ke dalam $10 \mathrm{~mL}$ aquadest. Kemudian $\mathrm{pH}$ meter dicelupkan ke dalam larutan dan diamati nilai $\mathrm{pH}$ sabun padat (Setyoningrum, 2010).

c. Uji daya busa

Pengujian daya busa dilakukan dengan cara menimbang sabun transparan sebanyak $5 \mathrm{~g}$ yang dilarutkan ke dalam $5 \mathrm{~mL}$ aquadest. Kemudian sabun dimasukkan ke dalam tabung reaksi dan dikocok lalu catat/ukur tinggi busa yang terbentuk setelah pengocokkan 30 detik dan 60 detik (Utami, 2011).

d. Uji Alkali Bebas

Sabun transparan sebanyak $20 \mathrm{~g}$ dilarutkan dengan aquadest sebanyak $50 \mathrm{~mL}$, kemudian ditambahkan 2 tetes indikator phenolphtalein dan dititrasi dengan menggunakan $\mathrm{HCl} 0,1 \mathrm{~N}$ hingga warna merah jambu hilang. Hasil titrasi yang diperoleh kemudian dicatat dan dilakukan pengulangan sebanyak 3 kali (Utami, 2011).

\section{HASIL DAN PEMBAHASAN}

\section{Pemurnian Minyak Goreng Bekas}

a. Penghilangan kotoran (despicing)

Proses despicing dilakukan dengan tujuan untuk memisahkan dan mengendap kotoran, partikel halus tersuspensi atau terbentuk koloid seperti protein, karbohidrat, garam, gula, dan bumbu rempah-rempah yang digunakan pada saat menggoreng bahan bahan pangan (Dahlan dkk., 2013). Kotoran-kotoran tersebut akan larut dalam air dan ikut mengendap di bawah air, sehingga didapatkan hasil minyak yang semula gelap menjadi berwarna kecoklatan. Campuran minyak dengan air kemudian dipisahkan dengan menggunakan corong pisah. Pada proses ini didapatkan dua lapisan, lapisan atas merupakan minyak dan lapisan bawah merupakan air. Hal tersebut dikarenakan berat jenis air lebih besar dari berat jenis minyak, berat jenis minyak yaitu 0,940$0,950 \mathrm{~g} / \mathrm{mL}$ sedangkan berat jenis air yaitu $1 \mathrm{~g} / \mathrm{mL}$ (Aisyah dkk., 2010).

\section{b. Proses netralisasi}

Proses netralisasi minyak goreng digunakan untuk memisahkan asam lemak bebas dari minyak dengan cara mereaksikan dengan basa. Reaksi yang terjadi antara asam lemak bebas dengan $\mathrm{NaOH}$ akan membentuk sabun yang dapat membantu pemisahan zat warna dan kotoran seperti fosfatida dan protein dengan cara membentuk emulsi sehingga mudah memisahkan asam lemak bebas dalam minyak yang besifat non polar (Kheang, 2006). Netralisasi dilakukan dengan cara mereaksikan minyak hasil proses despicing dengan $\mathrm{NaOH} 10 \%$. Penggunaan $\mathrm{NaOH} 10 \%$ sebagai basa dapat membantu mengurangi zat warna dan kotoran yang berupa getah serta lendir yang tidak dapat dihilangkan dengan proses despicing. Pada saat minyak hasil despicing dicampurkan dengan larutan $\mathrm{NaOH} 10 \%$ yang dipercepat dengan pemanasan dan pengadukan akan terbentuk butiran kecil-kecil dan lama-kelamaan warnanya berubah dari coklat menjadi kuning orange. Minyak netral yang dihasilkan berwarna orange dan bersih (Octarya dan Fernando, 2016).

\section{c. Proses pemucatan (bleaching)}

Proses bleaching bertujuan untuk menghilangkan warna coklat orange pada minyak dan senyawa-senyawa pengotor dalam minyak. Proses pemucatan dilakukan dengan mereaksikan minyak goreng bekas hasil proses netralisasi dengan menggunakan karbon aktif. Peningkatan suhu dalam proses pemucatan bertujuan untuk mempercepat reaksi antara karbon aktif dan adsorbat (senyawa peroksida) atau senyawa-senyawa pengotor (Novitriani dan Lin, 2013). Waktu dan pengadukan dalam proses pemucatan bertujuan untuk mencapai kesetimbangan adsorpsi, karena 
jika fase cairan yang berisi adsorben diam maka proses difusi akan berjalan dengan lambat. Pengadukan juga dilakukan agar partikel karbon aktif dapat bersinggungan dengan senyawa serapan, kemudian penyaringan bertingkat dilakukan untuk memisahkan karbon aktif dari minyak untuk mendapatkan hasil minyak yang terbebas dari kotoran dan berwarna kuning (Aisyah dkk, 2010)

Berdasarkan hasil pemurnian minyak goreng bekas menunjukkan warna minyak goreng bekas berubah menjadi lebih jernih dibandingkan sebelumnya. Hasil yang diperoleh dari proses pemurnian dengan tahapan despicing, netralisasi dan bleaching didapatkan minyak yang berwarna kuning jernih, tidak berbau tengik dan tidak terdapat kotoran. Hal ini sesuai dengan syarat mutu organoleptis minyak goreng menurut Standar Nasional Indonesia (SNI) 01-3741-2013 yaitu minyak goreng berwarna kuning sampai kuning pucat dan tidak berbau.

\section{Stabilisasi Bekatul Beras Merah (Oryza nivara)}

Stabilisasi dilakukan menggunakan oven pada suhu $80^{\circ} \mathrm{C}$ selama 1 jam untuk menginaktivasi enzim lipase dalam bekatul dan dapat menurunkan kadar air bekatul (Kim dkk., 2014). Hasil stabilisasi bekatul disajikan pada Gambar 1.

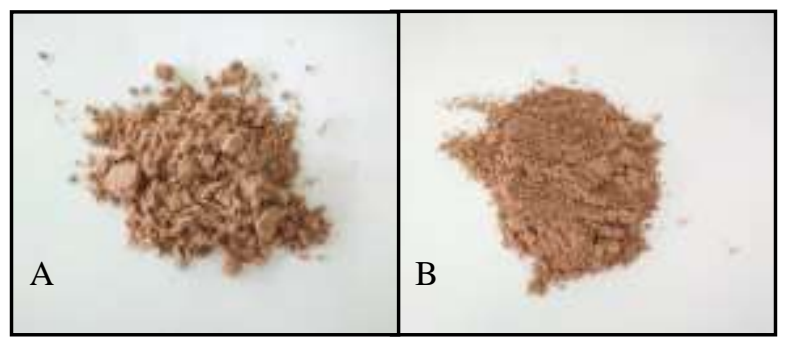

Gambar 1. Hasil stabilisasi bekatul beras merah (Oryza nivara) A) sebelum dan B) sesudah stabilisasi

Hasil bekatul yang belum mengalami proses stabilisasi memiliki ciri fisik berwarna coklat merah sesuai dengan pigmen dari beras merah, menggumpal dan terdapat enzim lipase dalam bekatul, sedangkan bekatul yang telah mengalami proses stabilisasi dengan oven memiliki hasil fisik berwarna coklat dan tidak menggumpal. Pada proses stabilisasi bekatul akan terjadi reaksi maillard yaitu reaksi pencoklatan non-enzimatis yang terjadi akibat adanya reaksi antara gula pereduksi (karbohidrat) dengan gugus amin bebas dari asam amino atau protein (Siswanti, 2018).

\section{Organoleptis}

Pengujian organoleptis sabun bertujuan untuk mengetahui bentuk, warna dan bau dari sabun transparan yang dihasilkan. Hasil sabun transparan disajikan pada Gambar 2.

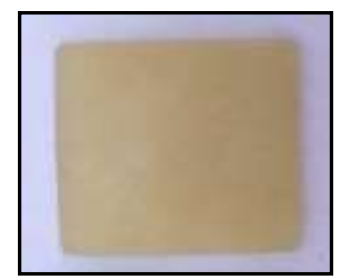

\section{Gambar 2. Organoleptis sabun transparan bekatul beras merah}

Sabun transparan bekatul beras merah berbahan minyak goreng bekas menghasilkan bentuk padat, berwarna kuning khas dari minyak goreng dan ekstrak bekatul yang berwarna coklat khas, serta beraroma khas bekatul. Hasil berupa sabun transparan ini dipengaruhi oleh proses pembuatan sabun (konsentrasi alkali, suhu, waktu dan pengadukan) serta kualitas bahan yang digunakan. 
Penambahan ekstrak mengakibatkan berkurangnya transparansi pada sabun transparan (Hernani dkk., 2010).

\section{Karakteristik Mutu Sabun Transparan Bekatul Beras Merah}

Hasil pengujian nilai $\mathrm{pH}$, daya busa, kadar air dan alkali bebas sabun transparan bekatul beras merah berbahan dasar minyak goreng bekas dapat dilihat pada Tabel II.

\begin{tabular}{lcc}
\multirow{2}{*}{ Tabel II. Karakteristik Sabun Transparan Bekatul Beras Merah } \\
\cline { 2 - 3 } Pengujian & \multicolumn{2}{c}{ Hasil Pengujian } \\
\hline $\mathrm{pH}$ & $10,20 \pm 0,00$ & Syarat (SNI, 1994) \\
Daya busa $(\mathrm{cm})$ & $2,54 \pm 0,01$ & $9-11$ \\
Kadar air $(\%)$ & $3,58 \pm 0,045$ & maks $15 \%$ \\
Alkali bebas & $0,03 \pm 0,00$ & maks 0,1 \\
\hline
\end{tabular}

Tabel II menunjukkan bahwa sabun transparan bekatul beras merah memiliki nilai pH 10,2 yang memenuhi persyaratan SNI (1994). Nilai pH sabun yang basa dapat membantu kulit untuk membuka pori-porinya kemudian busa dari sabun mengikat kotoran yang menempel pada kulit (Setyoningrum, 2010). Bahan tambahan lain dalam pembuatan sabun transparan juga mempengaruhi hasil pengujian nilai $\mathrm{pH}$ yaitu seperti aquadest dan gliserin (Widyasanti dkk., 2017).

Hasil pengujian daya busa sabun transparan bekatul beras merah memenuhi persyaratan mutu uji daya busa menurut SNI (1994) dengan hasil pengujian yaitu 2,54 cm. Busa yang tinggi saat proses penyabunan terjadi karena proses saponifikasi dari asam lemak dan basa terbentuk dengan sempurna. Busa yang cukup banyak menyebabkan daya pembersih sabun dapat berfungsi lebih baik untuk membersihkan. Aquadest yang ditambahkan pada saat pembuatan sabun juga berpengaruh terhadap busa yang dihasilkan, semakin banyak aquadest yang ditambahkan mengakibatkan daya busa semakin rendah (Utami, 2011).

Kadar air sabun 3,85\% yang memenuhi persyaratan. Pengukuran kadar air perlu dilakukan karena berpengaruh pada kualitas sabun. Semakin banyak kandungan air pada sabun maka sabun akan semakin mudah menyusut cepat habis saat digunakan dengan demikian semakin sedikit kadar air pada sabun maka akan mempengaruhi tekstur sabun yang lebih memadat (Susanti dan Guterres, 2018). Berdasakan penelitian Wijana dkk. 2009 tentang pembuatan sabun dengan minyak goreng bekas menunjukkan bahwa kadar air dalam sabun akan berpengaruh terhadap daya busa dan $\mathrm{pH}$ sabun, semakin tinggi kadar air maka daya busa sabun akan semakin rendah selain itu $\mathrm{pH}$ yang tinggi mengakibatkan kadar air semakin rendah dan daya busa akan semakin optimum.

Kandungan alkali bebas dalam sabun transparan bekatul beras merah adalah 0,03\% yang memenuhi syarat SNI (1994) dengan basa $\mathrm{NaOH}$ adalah $0,1 \%$. Alkali bebas yang terdapat dalam sabun disebabkan karena adanya konsentrasi $\mathrm{NaOH}$ yang berlebihan pada proses saponifikasi, sehingga $\mathrm{NaOH}$ tidak dapat berikatan dengan asam lemak bebas (Rozi, 2013). Alkali bebas yang rendah pada sabun menunjukkan bahwa $\mathrm{NaOH}$ yang digunakan hampir bereaksi seluruhnya dengan fase minyak sehingga sisa $\mathrm{NaOH}$ dari reaksi penyabunan semakin sedikit.

\section{KESIMPULAN}

Berdasarkan hasil penelitian yang telah dilakukan dapat disimpulkan bahwa sabun transparan bekatul beras merah (Oryza nivara) berbahan dasar minyak goreng bekas yang telah dimurnikan didapatkan hasil yang memenuhi persyaratan mutu sabun secara teori yang meliputi

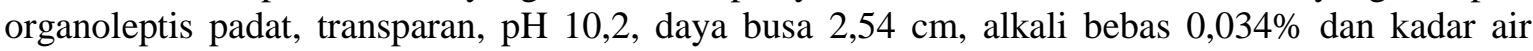
$3,85 \%$. 


\section{DAFTAR PUSTAKA}

Aisyah, S., Yulianti, E., Fasya, A.G., 2010, Penurunan Angka Peroksida dan Asam Lemak Bebas (FFA) pada Proses Bleaching Minyak Goreng Bekas oleh Karbon Aktif Polong Buah Kelor (Morina Oliefera. Lamk) dengan Aktivasi NaCl, Alchemy, 1(2): 53-103.

Badan Standarisasi Nasional, 1994, SNI 06-3532-1994. Standar Mutu Sabun Mandi. Jakarta: Dewan Standarisasi Nasional.

Dahlan, M.H., Siregar, H.P., dan Yusra M., 2013, Penggunaan Karbon Aktf dari Biji Kelor dapat Memurnikan Minyak Jelantah. Jurnal Teknik Kimia, 19(3): 44-53.

Goufo P., Trindade, H, 2014, Rice Antioxsidants: Phenolik Acids, Flavonoids, Anthocyanins, Proanthocyacianidins, Tocopherols, Tocotrienols, $\gamma$-Oyzanol and Phytic Acid, Food Science and Nutrition, 2(20): 75-104.

Hernani., Bunasor, T.K., dan Fitriati, 2010, Formula Sabun Transparan Antijamur dengan Bahan Aktif Ekstrak Lengkuas (Alpinia galanga L. Swartz.), Jurnal Bul. Littro, 21(2): 192-205.

Hardian, K., Ali, A., Yusmarini., 2014, Evaluasi Mutu Sabun Padat Transparan dari Minyak Goreng Bekas dengan Penambahan SLS (Sodium Lauryl Sulfate) dan Sukrosa. Jurnal Jom Faperta, 1(2).

Kheang, L. S., 2006, Recovery and Conversion of Palm Olein-Derived Used Frying Oil to Methyl Esters for Biodiesel, Journal of Oil Palm Research, 18: 247-252

Ketaren, S, 2005, Minyak dan Lemak Pangan. UI Press. Jakarta.

Kim, S. M., Hyun-Jung C., dan Seung-Taik L, 2014, Effect of Various heat Treatments on Rancidity and Some Bioactive Commpounds of Rice Bran, Journal of Cereal Science, 60:243-248.

Momuat, L.I. dan Wuntu, A.D, 2017, Produksi Sabun Mandi Transparan Berbahan Baku VCO mengandung Karotenoid Tomat, Jurnal Ilmiah Sains, 17(2):171-175.

Novitriani, K., dan Lin, I., 2013. Pemurnian Minyak Goreng Bekas. Jurnal Kesehatan Bakti Tunas Husada, 9(1):101-106.

Naomi, P., Gaol, A.M.L., Toha, Y, 2013, Pembuatan Sabun Lunak dari Minyak Goreng Bekas Ditinjau dari Kinetika Reaksi Kimia, Jurnal Teknik Kimia, 19(2): 42-28.

Octarya, Z. dan Fernando, A., 2016, Peningkatan Kualitas Minyak Goreng Bekas Dengan Menggunakan Arang Aktif dari Ampas Tebu yang Di Aktivasi Dengan NaCl. Jurnal Photon, 6(2): 139-148.

Priani, E. dan Lukmayani, 2010, Pemanfaatan Sabun Transparan Berbahan Dasar Minyak Jelantah dan Hasil Uji Iritasinya terhadap Kelinci, Prosiding SNaPP Edisi Eksakta, Jurusan Farmasi Unisba, Bandung.

Purwanti, A., Sumarni., Ariani, L., Dewi, F.K, 2017, Pembuatan Sabun Transparan dari Minyak Kelapa dengan Penambahan Antiseptik, Prosiding ReTII (Rekayasa Teknologi dan Informasi) ke 12, Sekolah Tinggi Teknologi Nasional, Yogyakarta.

Rozi, M, 2013, Formulasi Sediaan Sabun Mandi Transparan Minyak Atsiri Jeruk Nipis dengan Cocamid DEA, Skripsi, Universitas Muhammadiyah Surakarta.

Siswanti, Murhartadi, E., Anandito, R.B.K., dan Setyaningrum, E.A, 2018, Karakterisasi Sifat Fisik dan Kimia Bekatul Beras Hitam (Oryza sativa L.) Kultivar Melik dengan Berbagai Teknik Stabilisasi, Proseding Seminar Nasional Fakultas Pertanian Vol 2(1), Universitas Sebelas Maret.

Suhery, W.N., Anggraini, N, 2016, Formulation and Evaluation of Peel-off Gel Masks from Red Rice Bran Extract with Various Kind of Bases, International Journal of PharmTech Research, 9(12): 574-580.

Susanti, M.M dan Priamsari, M.R, 2019, Pemanfaatan Limbah Minyak Goreng Bekas dan Bekatul Menjadi Sabun Antiaging, Jurnal of Pharmacy, 8 (1): 8-14. 
Susanti, M.M dan Guterres A.D.A, 2018, Pengaruh Penambahan Kalium Hidroksida (KOH) Terhadap Mutu Sabun Lunak Berbahan Dasar Minyak Goreng Bekas, Jurnal Medsains, 4(1):25-33.

Setyoningrum, E.N.M, 2010, Optimasi Formula Sabun Transparan dengan Fase Minyak Virgin Coconut Oil dan Surfaktan Cocoamidropropyl Betadine, Aplikasi Desain Factorial, Skripsi, Universitas Sanata Dharma, Yogyakarta.

Tuarita, M.Z., Sadek, N.F., Sukarno, Yuliana, N.D., dan Budijanto, S, 2017, Pengembangan Bekatul sebagai Pangan Fungsional: Peluang, Hambatan, dan Tantangan, Jurnal Fakultas Teknologi Pertanian, 26 (2).

Utami W.P, 2011, Pembuatan Sabun Cair dari Minyak Goreng Bekas (Jelantah), Tugas Akhir, Universitas Sebelas Maret Surakarta.

Widyasanti, A., Nugraha, D., Rohdiana, D, 2017, Pembuatan Sabun Padat Transparan Berbasis Bahan Minyak Jarak Castor oli dengan Penambahan Bahan Aktif Ekstrak Teh Putih (Camellia sinensis), Jurnal Ilmu-Ilmu Pertanian, 1(2): 140-151.

Wijana, S., Soemarjo dan Titik, H., 2009, Studi Pembuatan sabun Cair Dari Daur Ulang Minyak Goreng Bekas (Kajian Pengaruh Lama Pengadukan dan Rasio Air: Sabun Terhadap Kualitas). Jurnal Teknologi Pertanian, 10(1): 54-61.

Winarsi, H, 2011, Antioksidan Alami dan Radikal Bebas, Kanisius, Yogyakarta.

Youngson, R, 2005, Antioksidan: Manfaat Vitamin C dan E Bagi Kesehatan, diterjemahkan oleh Susi Purwoko, Arcen, Jakarta. 